\title{
The Provisions of Supervisor Responsibility in the Jordanian Civil Code
}

\author{
Atef Salem Al-awamleh \\ Department of Law, Al-Salt Faculty for Human sciences, Al Balqa Applied University, PO Box: 19117
}

\begin{abstract}
Neither harm nor malice, he who inflicted harm on others shall have personal and direct responsibilitytowards the injured party.He is legally obliged in his personal capacity for liability and damage reparation.For the purpose of granting the injured party a more favorable interest, the law provided for additional responsibility, in deviation from the original rule, called the Supervisor Responsibility, that grants the injured party the right toreferto a person other than the perpetrator of the damage if there are conditions and descriptions in both the perpetrator of the damage and the third party to whom the injured party has the right to refer to guarantee the damage.This study aims to clarify these personal conditions and descriptions, the relationship of the damageperpetrator with the third party who will holds direct liability, the guarantee of the harmful act, the statement of the basis of suchresponsibility, and the special and general aspects of defense made by the supervisors to hold themselves not responsible.
\end{abstract}

Keywords: Assumed Responsibility; Supervisors; Damage; Actual Authority

DOI: $10.7176 / \mathrm{JLPG} / 86-10$

Publication date:June $30^{\text {th }} 2019$

\section{Introduction}

The Jordanian legislator has organized the sources of personal right, including without limitation (Sources of Obligation). When any case is realized, this case shall be subject to the provisions of these definite resources. According to such sources, the source of obligation and personal responsibility shall be determined. This means that, a person shall be liable for his own act and no person shall be liable for the act of another.

And that the harmful act as one of the main sources of obligation, and the establishment of civil liability is personal in the first place, that is, anyone who causes damage to others shall be solely responsible for the damage caused, and therefore shall be liable for damage reparation and shall bear full responsibility for the damage caused to others.

However, the Jordanian legislator has followed other modern legislation to highlight an original liability governed by the law and justified by practical reality, and caring for a better interest, that is the interest of the victim, by determining a joint liabilityon the natural or legal person who is bound by a specific association with the one who commits the damage as a departure from the general role of damages contained in Article 256 of the Civil Code. ${ }^{1}$

Most of the provisions of liability in the Jordanian Civil Code are an extension of the Judicial Provisions Journal $^{2}$, most of which provisions are derived from Islamic jurisprudence. However, some Islamic jurisprudence holds that Islamic law does not accept the principle of responsibility for the actions of others based on the verse (Nor can a bearer of burdens bear another's burdens) ${ }^{3}$. And the Almighty says: (On no soul doth Allah Place a burden greater than it can bear.It gets every good that it earns, and it suffers every ill that it earns)Based on these verses, they decide that man will only be asked about his personal deeds. Some ${ }^{4}$. jurisprudence went on to say that what the Jordanian legislator ruled in this regard is contrary to the principle adopted by the Islamic law that a person is notliable for the damage caused to a third party.

However, another aspect of the jurisprudence responded that what is related to these texts is that the one committing damage shall bear the torment in the Hereafter, and that the Islamic jurisprudence has known many forms of responsibilityfor the actions of others. An incident is mentioned in "Al-Kharaj" book (land Text) written by Imam Abu-Yousuf thatstates:(A man came to Caliph Omar bin Abdul-Aziz and said, "O Commander of the Believers, I planted [my land] but an army of the Levant people passed and they spoiled it, and so the Caliph compensated him with ten thousand dirhams). Therefore, there is nothing to prevent the Islamic jurisprudent from being held responsible for someone else's action.

Considering the nature of the Jordanian legislator of dealingrationally with legislation, especially in terms

\footnotetext{
${ }^{1}$ See Article (256) of the Jordanian Civil Code: (Any damage to third parties obligates an actor, even if not privileged, to ensure damage). ${ }^{2}$ Journal of Judicial Judgments: It is a collection of legislation, consisting of sixteen books, issued during the Ottoman rule in 1882 , and was applied in most Arab countries, including Jordan, and is the basis and legal source for many Arab laws, especially the Civil Code, With the issuance of the Civil Law No. (43) of 1976

${ }^{3}$ Quran, Surah Al-Zomor, (7)

${ }^{4}$ Quran, Surah Al-Baqarah, (286)

${ }^{5}$ Book of abscess to Imam Abu Yusuf (Judge Abu Yusuf Yaqoub ibn Ibrahim), p. 119
} 
of the financial rights, by adopting the provisions and principles of Islamic Shari'ah, as well as responding to the requirements of reality and the modern state, the first paragraph of Article (288) of the Jordanian Civil Code provides(...Any person who is under a legal or a contractual obligation to supervise a person in need of supervision due to his minority or his mental or physical condition, unless he proves that he has fulfilled his duty of supervision or that damage was to be inflicted even though he fulfilled his duty of supervision or that the damage was to be inflicted even though he performed this duty with due care).

When a person who is subject to supervision causes damage to others because of his illegal action, the person in charge of supervision shall be directly responsible towards the injured party and shall be obliged to pay the value of the damage incurred without any increase or decrease.

\subsection{Study Significance}

The significance of this study is reflected in the statement of the provisions of the regulatory legal rules governing supervisor'sresponsibility and the conditions for their realization. These provisions are put into effect by extrapolating the principles and judgments issued by the Jordanian Court of Cassation. The study significance is also reflected in the statement of a major source of compliance which is the law, taking into account that this additional responsibility is exceptional to the original provision under the law, and the addition of a new financial liability for the damage perpetrator in order to guarantee liability and damage reparation inflicted on the injured party, and the injured party'sbenefit of the additional financial solvency of the requirement ofthe necessary compensation in case of financial insolvency of the damage perpetrator.

\subsection{Study Problem}

The problem of this study lies in raising several questions, the most important of which being: What is the responsibility of the supervisors and when can the injured party benefit from the legal provision that covers this responsibility, reference to the supervisors, and the ability of the supervisors in defendingthis mandatory responsibility imposed on his financial liability.

\subsection{Research Methodology}

The researcher has used the analytic descriptive approach, through searching and analyzing relative legal provisions, as well as the statement of jurisprudence opinions, and extrapolating the judgments and principles issued by the Jordanian Court of Cassation.

\subsection{Research Structure}

To clarify the provisions of realizing this responsibility, it is necessary to indicate the responsibility of what is a supervisor, the basis on which responsibility is established and the meeting of both the supervisor responsibility with the responsibility of the supervised person and the damage for which he is compensated through the following topics:

\section{What is a Supervisor}

This topic will be discussed through two requirements: First, the definition of supervisors, second, the conditions for realizing the responsibility of supervisors.

\subsection{Definition of Supervisors}

The legislator has not directly defined supervisors, but through the text of the Article that regulates the provisions of supervisor responsibility, a definition can be extracted from the same text. This is the legislative intent of the legislator in some cases in not defining some terms and thus leaving them to jurisprudence and to the judge to decide according to the situation presented so that the legislator may not make mistakes when expanding the definition or narrowing it which has a negative impact on reality.

Therefore, jurisprudence took the responsibility of defining supervision. Initially, some jurisprudence defines supervision as being: (A person's obligation to supervise, advise and guide another person in a way that insures not inflicting damage on others.) ${ }^{1}$ Others define a supervisor as: (A person who takes care of indiscriminating minors or who are mentally equal to them such as crazy people and manage their affairs, or those who supervise who physically disabled). ${ }^{2}$ Others have also defined a supervisor as: (Any person who is legally and contractually bound to supervise another person). ${ }^{3}$ Responsibility has been defined as:(Eligibility of a person to attribute his action to himself and be held accountable for it). Or it is defined as :(The liability arising from the words or actions issued by a responsible person and on which effects of this world and the other world are based).

${ }^{1}$ Al-Hajri, Masha'el, Responsibility for Doing Other, Kuwait University, Faculty of Law, p. 4

${ }^{2}$ Al-Sarhan, Adnan, Khater, Nuri (2003) Explain the Civil Code (Sources of Personal Rights), Amman, Dar Al-Thaqafa, p. 517

${ }^{3}$ Al-Hajri, Mishael, op. Cit., P. 4. 
It is also defined as: (The state of a person who commits an offense that he shall be blamed for it. ${ }^{1}$ Responsibility for the action of others is defined as: (A person being bound to compensate for the damage caused by another party because of having an association between them $)^{2}$

In the light of the above, it has become clear that responsibility is the guarantee and liability of a person under the law or contract for the act of others as a result for his responsibility for the supervision, direction and the actual authority of this person towards third parties.

The clearest Arabic law in defining supervisor responsibility is the Egyptian legislation. The Egyptian Civil Law provides: (Whoever shall legally or contractually supervise a person in need of supervision because of being a minor or because of his mental or physical condition shall be liable to compensate for the damage inflicted by such to others through his illegal action) $)^{3}$

\subsection{Conditions of Realizing Supervisor Responsibility}

To realize the responsibility for the action of others, certain conditions must be met so that if one of these conditions is not met, the responsibility is not realized. For the injured party to be able to challenge the supervisors, two conditions must be fulfilled:

\subsubsection{Having Commitment towards Supervision}

For a supervisor to be responsible for the damaging action inflicted by the supervised person, there should be commitment of the supervisor to supervision through law or contract.

1. Legal Supervision: Legal supervision is determined in stipulation of law provisions such as custody ${ }^{4}$, or by legal judgment such as the guardian on minors or insane people who are over 18 years old. This includes the obligation imposed by the law on the father to supervise his minor son. This was adopted by the respectable Court of Cassation, where it ruled in one of its judgments the following: (If the defendant (Sara) is the one who caused damage to the child (Ala'a) at his eye, and since her father is responsible for supervising her because of her minority, therefore, in stipulation with the provisions of Article 288 of the Civil Code he shall be liable for compensation for damage $)^{5}$

The reason behind such supervision is that the person needs it, whether he is a minor or a person with mental or physical disability. In all these cases, the supervised person needs care and supervision from others which is originally proved for minors by a guardian whether it be a father, a grandfather, an uncle or any other person. ${ }^{6}$

This authority is different from guarding money as well as its being different from guarding the self because protection is the basis of responsibility (directly concerned with the person who is put under protection when he is a minor in terms of his money. Nevertheless, no guardianship is imposed for anybody on himself and no authority shall be in terms of his own person. ${ }^{7}$

As can be seen in the provision of Article 288/1 of the Civil Code, law has not defined the persons who needs supervision, where it was satisfied by indicating that supervision obligation may be caused by the minority of the person who is under supervision, or the person's mental or physical condition. Therefore, a person shall be under supervision if he has not reached 18 years of age. ${ }^{8}$ And that his mental condition determines making supervision on him whether he has reached the legibility age such as insane persons. In addition, the physical condition of the person that requires legal supervision and the consideration of the latter case, which is the physical condition of the person that requires legal control, such as the blind, and amputation of hands or feet or having a double disability such as deafness and dumbness, or blindness and deafness, etc. in spite of completion of the age of eligibility although the law does not consider these physical cases as requiring a custody or guardianship or as a symptom of eligibility.

2. Contractual Supervision: To realize contractual supervision, it shall be preceded by a legal supervision and then there would be a move under an agreement from the legal supervisor to the other party in the contract, despite the fact that the nature of the that contract between the supervisor and the third party is completely different from this responsibility. For example, when a parent takes his son to school, this is done under an education contract, and when the guardian takes an insane person whom he supervises to the hospital of mental disease this is a contract of health care and protection. However, with the actual transfer and control of the supervised person from the supervisor to the third party under the contract, regardless of

\footnotetext{
${ }^{1}$ Al-Rashidi, Mishary (2010). The Uncertainty Responsibility for Harmful Action - Comparative Study - Master Thesis, Middle East University, p. 13

${ }^{2}$ Al-Hajri, Mishael, op. Cit., P. 4.

${ }^{3}$ See the text of article 173 of the Egyptian Civil Code No. 131 of the year

${ }^{4}$ See: In the state what is stated in Article (123) of the Civil Code: (the little guardian is his father and then guardian of his father and then his grandfather and then the guardian of the grandfather and then the court or the court's recommended)

${ }^{5}$ See the decision of the Court of Excellence of Jordan in its criminal capacity No. (47/2007) dated 7/3/2007.

${ }^{6}$ Mansour, Amjad (2006). General Theory of Obligations, 1, Amman, Dar Al-Thaqafa, p. 310

${ }^{7}$ Mark, Solomon (1992). Al-Wafi in explaining the civil law (in obligations), Volume II, I 5, Cairo, p. 745

${ }^{8}$ See Article 43 (2) of the Civil Code: (the age of majority is eighteen full solar years)
} 
the nature of this contract, the responsibility for damage inflicted on the third party is also transferred without the need to provide for such responsibility under the contract.This was confirmed by the Court of Cassation in one of its judgments where it stated: (If the appellant has actual authority on the student who caused the damage in terms of supervision and guidance within the meaning of Article 288/1 / b of the Civil Code, the appellant shall be responsible for the student's action and for reparation of the subsequent damage inflicted on the appellee) $)^{1}$

Based on what has been previously mentioned, the basic element of responsibility is realizing actual supervision, authority and guidance. This is the first pillar, and the second is the presence of two people, one of whom is legally and contractually in charge of supervising the other. This assignment under the law, represents the father, or under contract between the supervisors and others, such as a father's contract with the school.

\subsubsection{The Supervised person committing a harmful action that causes damage to a third party}

A harmful act in general is either positive or negative, and in the case of the supervised person, the act to be held accountable is only the act that is positive, that is, a positive act of the supervised person that causes damage to others thus requiring responsibility and guarantee.

The provisions of Article 256 of the Civil Code apply in this regard, i.e. there is no requirement for discern, nor is there a requirement that an error be found on the side of the person responsible for the damage. Had it required such an error, it would not have been possible to hold the undiscerning child or insane person liable for the harm caused by either of them because they lack the will, and the error is related to the existence of will ${ }^{2}$

It is therefore necessary for the supervisors to have the responsibility of the minor when that minor commits an act that is considered a breach of duty or a deviation from the behavior of the average person, regardless of the availability or lack of availability of the element of recognition or discerning. The legislator has considered that the responsibility of the supervisor or the caregiver is not based on the error committed by the supervised person, but on the basis of the supervisor's error.

One of the judgments issued by the Court of cassation in this regard is its Judgment No. 3352/1999:(Article 288 of the Civil Code provides that a person who raises and controls a minor is responsible for the damage he causes to others in his illegal work and is obliged to compensate the injured party. This responsibility is based on a presumed error in the interest of the injured party,a violation of the supervisors ....).

That is, it is not enough for such responsibility that the perpetrator to be subject to the supervision of a person whose civil liability is due to such an act. It is also necessary that such an act be a breach of a legal duty or a deviation from the conduct of the ordinary man if found in circumstances like the apparent circumstances in which the supervised subject was found. The psychological element of the error is not required, although this latter element is a necessary element of the error that imposes liability, but the responsibility of the supervisor is not based on the error committed by the supervised person, but is based on his fault in supervising the latter.This means that it is based on the violation of the duty of supervising the latter, and that this duty is not absolute, that it imposes on the supervisor the prevention of any harmful action falls from the supervised person, even if it were the use of a right or a legitimate act that any person may commit without being held responsible, and that it should be limited to preventing the supervised person from committing harmful acts or wrongful acts that he unlawfully committed. ${ }^{3}$

It is not consistent with logic and with the needs of society to attach the responsibility of those who should be given care in all cases to the error of the covered, But the legislator noted, on the other hand, that the caregiver should not be held accountable for any act of care. Therefore, in these acts it is enough to have the element of error which is (trespass) without the need for the moral element of discrimination. ${ }^{4}$

It should also be noted that to realize the responsibility of the supervisors for the damage caused by the supervised person to others, the action of the supervised person alone must be the one that has caused this damage to others. That is to be the direct cause without having other reasons, because if other reasons met, it must be considered whether the act of the supervised person is direct or causative.If it is direct, and the other reasons causing damage are (secondary) the supervised person shall be held responsible for the harmful act and therefore the responsibility of the supervisors. But if the damage is causative, there shall be no responsibility, based on the provision of Article $(257)^{5}$, unless the damaging act is associated with trespass or intent or the act leads to harm. In practice, there is no responsibility as the situation of the supervised person contradicts with the two conditions of trespass or intent based on the will and perception, and there is no objection to holding responsibility in the third case that the act of the perpetrator of damage is the one that caused the damage.

\footnotetext{
${ }^{1}$ The decision of the Court of Cassation of Jordan in its capacity as a jurist No. (1407/2005), a quorum, dated 6/9/2005.

${ }^{2}$ Al-Far, Abdul Qadir (2015). Sources of Obligation (Sources of Personal Rights in Civil Law), I 6, Amman, Dar Al-Thaqafa, p. 182.

3 Mark, Solomon, op. Cit., P. 773.

${ }^{4}$ Danon, Hassan, (1976). General Theory of Obligations, Baghdad, University of Mustansiriya, p. 324

${ }^{5}$ See: Article 257 of the Civil Code: (1) The damage to direct or cause. 2 - If the direct obligation of the guarantee and no condition, and if signed by causing the requirement of infringement or intent or that the act leads to damage)
} 
However, this does not preclude the responsibility of the supervised person and thus the responsibility of the supervisors, if the damage is caused by the supervised person with the participation of another person. In this case, he shall be held responsible by the amount and rate of his contribution to the harmful act and the time of realizing the damage, not the time of claiming it. This was indicated by the Court of Cassation in one of its judgments: (The person who is responsible for the education and control of a minor, shall be responsible for the damage caused to others with his illegal work, which is a violation of the supervisors such as the father of the minor... and where it is established from the evidence available in the case, that Ayman the son of the appellant, when he was a minor, seized in partnership with another the money belonging to the appellee, which he returned part of it and did not return the rest of the amount claimed in this lawsuit.Therefore, in stipulation with the provisions of Article 288, he shall be liable for the damage and shall be obliged to return the amount. This liability shall not be acquitted when the minor becomes an adult, as the judgment is based on the date of the injury occurrence... $)^{1}$.

Unless the supervised person is a means or instrument in the hands of others to commit a malicious act and to achieve harm, such as the others' willingly use or exploitation of a non-discerned or insane person to harm others. Therefore, the supervised person shall not be held responsible for the harm caused to the injured party, and the supervisor shall not be held responsible, either.

Whereas the responsibility of the supervisors is a liability of subordination that is established only in accordance with the establishment of responsibility of the supervised person, the injured party may choose the way he wishes to file the claim, either against the one who caused the damage or against the supervisors or both. In the case of getting his compensation from the one who committed the damaged action (the supervised person)he has no recourse to the supervisors after that, since the injured party can only receive one compensation. ${ }^{2}$

This has been confirmed by the Court of Cassation in one of its judgment by stating, (The option is also left to the victim to refer to the person who committed the error in particular if he has money, or to return to the supervisors, and the most important thing is that he does not receive compensation twice, and where it was not established on the side of the appellant any reasons that shift his responsibility for the act of his minor son and his dispute, the litigation shall continue to sentence him as guardian of his son and legally responsible for his upbringing and control ...). ${ }^{3}$

It is also necessary for the victim to prove that the damage is the result of the supervised person act, that is, the responsibility of the supervised person must first be fulfilled until the responsibility of the supervisors is realized based on supervision negligence.

The responsibility of the supervisor is for the illegal acts inflicted by the supervised person on others, not for the acts that fall upon him, either from a foreigner or from himself. Therefore, if a foreigner caused harm a student during the supervision of the school, or if the pupil has been personally harmed in that period, the school shall not be held responsible in both cases. ${ }^{4}$

Not all the actions that are committed by the supervised person shall be the responsibility of supervisors, and therefore distinction shall be made in accordance with the case of the supervised person of control. Accordingly, supervision shall be determined, for example, young or insane persons, supervisors shall be responsible for the harmful actions of the young and the insane.

As for persons with physical disability, such as the blind or the paraplegic, the supervisor shall not be responsible, except for the damage that the supervised persons causes to a third party under this physical disability. Therefore, the supervisor shall be responsible for the blind's breaking the neighbor's glass because of dropping his caneand shall not be responsible for abusive words said by the blind to his neighbor as long as being an adult.

\subsection{The Basis of the Supervisor Responsibility}

The supervisor's responsibility is based on the assumed error in his part, in the sense that if the supervised person committed an illegal action, it is said that the supervisor has neglected his supervision or abused his upbringing, and the assumption of error in this regard implies assuming the causative association also. The injured party is exempted of proving the error and proving causation. The assumption of causality between error and damage is a natural consequence of the assumption of error ${ }^{5}$.

It is noted that the assumption of error is established only in the relationship between the supervisors and the injured party. It is an assumption decided by the law in favor of the injured party against the supervisors and may not be against the supervised person. Therefore, the injured party, and the supervisor cannot invoke before

${ }^{1}$ See: Decision of the Court of Cassation of Jordan in its Jurisdiction No. (3352/1999) Five-Body, dated 27/1/2000

${ }^{2}$ Obaidat, Yusuf, (2009). Sources of Compliance in the Civil Law, 1, Amman, Dar al-Masirah, p.352

${ }^{3}$ See: Decision of the Court of Cassation of Jordan in its Jurisdiction No. (3352/1999) Five-Body, dated 27/1/2000.

${ }^{4} \mathrm{Abu}$ Setit, Ahmed, (d, n). Sources of Commitment, p. 476

${ }^{5}$ Swar, Wahiduddin (1978). General Theory of Commitment, C1, Damascus, New Printing Press, p. 127 
the supervised person, but it is necessary to refer to this proof of error in his part ${ }^{1}$.

The responsibility in the case of the supervisors is apt to prove otherwise. The assumed error on the side of the supervisors is apt to prove otherwise. The supervisors can deny this error by proving that they have performed the duty of supervision and that they have taken reasonable precautions to prevent the supervised persons from inflicting damage to third parties. ${ }^{2}$ Therefore, the supervisors should defend themselves of being liable through the following:

a. That he has carried out the supervision duty. This has been indicated by the Court of Cassation in its judgment which states:(Article 288 of the Civil Code provides that a person who is responsible for the upbringing of a minor shall be liable for the damage caused to others by his illegal act and he shall be liable to compensation to the injured party...so that he cannot avoid responsibility for himself unless he had carried out the duty of control or that the damage was inevitable, even if he performed this duty with due care... $)^{3}$

As required by this duty and on a case-by-case basis, and due diligence in each case. In a case requiring the attention of the ordinary man, such as the supervision of a minor aged 15 years, while the supervision of a madman requires special attention. Therefore, the supervision criterion is in accordance with the condition of the supervised person, and the required care is the care of the average man (middle care), or the care of a keen man (special and strict care).

b. Deny the causal relationship, and the supervisor can deny the causal relationship by the foreign reason, which is the force majeure, sudden incident, or the action of others without the supervised person having a role in causing damage to others, or the act of the injured party itself ${ }^{4}$.

c. The damage is to be inflicted with by the supervised person committing anact as expressly stated by the legislator in the provision of Article 288/1 (a) or that the damage was unavoidable even if he performed this duty with due care), and the fact that it is very difficult to meet the two sides, the damage from the supervised person, and the supervisor's proof that the damage is to be inflicted.If the supervisor does not refute responsibility through the previous cases, then responsibility becomes in this situation not apt to prove otherwise and therefore the legislator was not right providing a text in this way to deny the responsibility of the supervisors because of the lack of compatibility with the reality and with the basis of responsibility.

\section{The Meeting of the Supervisor Responsibility and the Supervised Person Responsibility forDamage Reparation}

The original claim is that the injured party refers to the one who inflicted the damage (the supervised person), and the dispute here is original, but the claim must be filed by the legal representative, and here the inclusion of the legal supervisor in the case without the agreement only for purposes of serving summons and the validity of the dispute ${ }^{5}$. The legal deputy shall be notified by law of the existence of the case.

If the injured party returns to claim the reparation of the damage that is caused by the supervised person and the legal supervisors, the supervisor here has two capacities: the first as guardian or custodian of the supervised person, for the validity of the dispute and the validity of the notification procedures ${ }^{6}$, and as such, the first capacity is a formal procedure for the purposes of the litigation validity and the second capacity as a legally binding defendant for reparation for the wrongful act of the supervised person.

The last assumption is in the case committing the harmful act during the contractual supervision where, the case of the injured party is filed against the contractual supervisor to which the supervision is transferred from the legal supervisors, and against the supervised person and his legal representative, who in most cases is the legal supervisor. However, as noted earlier, the inclusion of the supervisors here is for the purposes of the validity of the litigation, i.e he is not an original party in the case. In other words, attachment can't be implemented on the funds of the supervisors (the legal representative), because he does not appear in the case as a defendant.

The question that comes to mind, in the event of a harmful act and the damage caused by the supervised person occurred during the contractual supervision, is whether the injured party can refer directly to the legal supervisors to demand reparation, without reference to the contractual supervisors.

To answer this question, two ideas must be discussed: the first, the rule of relative effect of contracts. That is, the provisions of the contract are only between the contractors, and do not apply to the right of others either

\footnotetext{
${ }^{1}$ Senhoury, Abdul Razak (1952). Sources of Commitment, Cairo, Publishing House of Egyptian Universities, p. 1006

${ }^{2}$ Senhoury, Abdul Razzaq, previous reference, p. 1007

${ }^{3}$ See: Decision of the Jordanian Court of Excellence (Rights) No. (2510/2008), dated 29/4/2009

${ }^{4}$ See Article 261 of the Civil Code: If the person proves that the damage was caused by a foreign cause that does not have a celestial caste, a sudden accident, force majeure, the act of others, or the act of the victim, he is not obliged to guarantee unless the law or agreement otherwise requires.

${ }^{5}$ See Article 18 of the Jordanian Civil Procedure Law No. 31 of 2017.

${ }^{6}$ See: Article 1616 of the Journal of Judgments
} 
negatively or positively ${ }^{1}$, with the exception of the right to give a third party their right, and therefore, the origin is the responsibility of the legal supervisors to face the injured party, and where the contract concluded between the legal supervisors and the contractual supervisors, whose provisions without the need to stipulate in the contract the transfer of supervision and its consequent responsibility to the contractual supervisors, is to take away the right of the injured party to refer to the judiciary, and to file a lawsuit against the legal supervisor, and therefore it is a violation of rule of relative effect of contracts on contractors, where the impact of the contract extends to the injured party by preventing him from contesting the legal supervisors and including him the lawsuit as a defendant.

The second idea: in the case of an agreement between the legal supervisors and the contractual supervisors, on exemption from liability in the event of the supervised person committing a damage that is harmful to others, for example when an insane person is entered in the hospital of mental disease, the supervision is transferred with its requirements to the hospital, including non-damage. Under the contract law, the parties agree that the hospital is not responsible for the damage caused by the supervised insane person. Does this exemption apply to the injured party?

To answer the above question, we must refer to the purpose established by law to provide for this exceptional responsibility, namely, to provide the injured party's interest as a first and best interest to the rest of the other parties, and to install additional financial guarantee for reparation of the damage inflicted on the injured party. If there is no legal provision preventing any reference to either of them, the injured person will have the choice to refer to either of them. He refers to the person who inflicted the damage (supervised person) if he has money, and this is the origin. He can refer to both the one who inflicted the damage and to the legal supervisors together, And due attention to and follow-up by the legal supervisors, due to the error in care, attention and guard by the legal supervisors. He can also refer to the contractual supervisors alone for the existence of the error on its part, and based on its capacity as the owner of actual authority in the control and guidance. Therefore, there is no effect on confronting the contractual injured of exemption from liability with the legal supervisors.

The supervised person inflicting a harmful action is not enough for the injured party to refer to the supervisors. The damage must be realized, i.e., actual damage, whether material or moral. To indicate the provisions of the damage in this responsibility,we refer to the provisions of tort liability, which the Jordanian legislator has built on three pillars: the harmful act, the causative relationship, and damage.

Material damage is the damage that affects the human body and money, which is most likely. This damage must be inflicted, that it has occurred or will inevitably occur, but the perpetrator shall not be responsible for the potential damage, since it is an unrealized damage that may occur and may not occur. A distinction must be made between the irreparable harm and the missed opportunity, which would be compensable. ${ }^{2}$

As for the moral damage, the Jordanian legislator defined it as: (...Any person who infringes the others' freedom, honor, reputation, social status or financial consideration in a way that makes the aggressor responsible for the guarantee. ${ }^{3}$ Thus, damage reparation shall be in accordance with the prescribed civil obligations, which are to restore the situation to the extent that it is, if possible, or compensation equivalent to damage. ${ }^{4}$

\section{Conclusion}

In the shade of the rise of damage cases inflicted by the supervised person on third parties, and in consideration of life development, and the rise in technological causatives, the rise in contractual supervision, the decline in the level of the required supervision and care, which requires the legislator to expand the regulation of the two kinds of supervisor responsibility, to accommodate the newly created cases, fill the legal gaps, and prevent conflict of responsibility, and conflict with other special laws. At the end of this study, the researcher has concluded the following results and recommendations:

1. The need to amend the provision of Article (288/1) and delete the words (no one is asked about the act of others) because it is unnecessary, and we find no similar in other laws, and because it is a general rule, and so there is no need to re-remind of it.

2. The need to amend the provision of Article (288/1) to oblige the court to perform the guarantee against the person who caused the damage to be consistent with the provisions of Article 256 of the same law. The court shall be obliged to perform the guarantee jointly with the supervisor in accordance with the conditions of its application. In this way, the Article shall provide as follows:(The Court shall, upon the request of the injured party, be obliged to perform the ruled guarantee on the person who caused the damage and / or who: (a) is required by law....).

\footnotetext{
${ }^{1}$ See Article (208) of the Jordanian Civil Code.

${ }^{2}$ Al-Far, Abdul Qadir, op. Cit., P. 189.

${ }^{3}$ See: Article 267 of the Jordanian Civil Code

${ }^{4}$ See the text of article 269/2 of the Civil Code: (It is estimated that the court may, depending on the circumstances and at the request of the injured party, order the return of the case to the same or control the performance of a specific order connected to the harmful act, as a matter of inclusion)
} 
3. Amend the provision of Article (288/2):(and for the one who performed the guarantee has to be paid by the convicted person). Who is the convicted person, the supervisors of the control, or the perpetrator of the damage? so that the supervisors must be sentenced in order to carry out implementation on him. Therefore, he cannot refer to himself, and so the Article must be amended as follows: (If the supervisor performed the guarantee, he has to be paid by the person who inflicted the damage).

4. Expressly provide that the right of the injured party to refer to the legal supervisors, even in the presence of the contractual supervision, because it is the original, which gave the contractual supervisor this capacity, with the right of the legal supervisor to refer to the author of person who inflicted the damage, or to the contractual supervisor, unless the contract provides for the exemption of the contractual supervisor from any liability.

5. Give an exception in the Article that it is not permissible to detain the supervisors if a judgment is issued against him, if he is convicted, if he proves his incompetence, and to attach the phrase "...." Notwithstanding the provision of any other law, it is not permissible to detain the indebted (the convicted), if it is found that he is sentenced with the capacity of being a supervisor if he proves incompetence) ${ }^{1}$

\section{Sources and References:}

\section{First: Sources:}

1- The Holy Quran.

2. Laws: Law of Civil Procedure No. 31 of 2017. Jordanian Execution Law No. 29 of 2017. Jordanian Civil Law 43 of 1976. Egyptian Civil Law No. 31 of 1948. Journal of Judgments.

3. Decisions of the Court of Cassation

\section{Second: References:}

- $\quad$ Abu Setit, Ahmed, (d, n). Commitment sources .Danon, Hassan, (1976).

- General Theory of Obligations, Baghdad, University of Mustansiriya. Al-Rashidi, Mishary (2010).

- The Responsibility of the Non-Distinguished to the Harmful Action - Comparative Study - Master Thesis, Middle East University.

- Sarhan, Adnan, Khater, Nuri (2003).

- $\quad$ Explanation of civil law (sources of personal rights), Amman, House of Culture.

- Senhoury, Abdul Razak (1952). Sources of Commitment, Cairo, Publishing House for Egyptian Universities.

- Swar, Wahiduddin (1978). General Theory of Commitment, C1, Damascus, New Printing Press. Obaidat, Youssef, (2009).

- $\quad$ Sources of Compliance in Civil Law, 1, Amman, Dar Al-Masirah.

- Al-Far, Abdul Qadir (2015). Sources of Obligation (Sources of Personal Rights in Civil Law), I 6, Amman, Dar Al-Thaqafa.

- $\quad$ Book of abscess to Imam Abu Yusuf (Judge Abi Yusuf Yacoub ibn Ibrahim). Mark, Solomon (1992).

- $\quad$ Al-Wafi in explaining civil law (in obligations), vol. II, I 5, Cairo.

- Mansour, Amjad (2006). General Theory of Obligations, I 1, Amman, Dar al-Thaqafa. Al-Hajri, Masha'el, Responsibility for Doing Other, Kuwait University, Faculty of Law

\footnotetext{
${ }^{1}$ Article (22) of the Jordanian Execution Law No. 29 of 2017, which states: (a) A creditor may request the imprisonment of a debtor if he fails to pay the debt or offers a settlement commensurate with his financial ability during the notice period, provided that the first payment under the settlement is not less than $25 \%$ of the amount awarded .......... B - The creditor may request the imprisonment of a city without the need to prove his competence in the following cases: 1 . Compensation for damages resulting from a criminal offense
} 